\title{
Profitablity Analysis of Bharat Plastics Industries
}

\author{
CS Gowtham Chakravarthy, S. Praveen Kumar
}

\begin{abstract}
The focal point of money related position is on key figures in the fiscal summaries and the critical relationship that exists between them the examination of budget reports to acquire a superior comprehension of the inflexible stance's and execution, budgetary position is the procedure of determination, connection and assessment. A budget report is a gathering of information which is legitimately and reliably sorted out as per bookkeeping standards a comprehension of some monetary parts of a business firm. It might demonstrate a situation at a minute in time, as on account of an asset report or may uncover a progression of exercises over a given timeframe as on account of a salary explanation.
\end{abstract}

Keywords: Budget, Salary, Time frame

\section{INTRODUCTION}

Benefit examination (additionally alluded to as bookkeeping investigation) alludes to an appraisal of the suitability, solidness and gainfulness of a business, sub-business or venture[1],[3],[5].

It is performed by experts who get ready reports utilizing proportions that utilize data taken from Profitability articulations and different reports. These reports are normally displayed to top administration as one of their bases in settling on business choices. In light of these reports, the executives may[2],[4],[6]:

Continue or suspend its fundamental activity or part of its business; item;

Make or buy certain materials in the assembling of its

Acquire or lease/rent certain apparatuses and hardware in the creation of its products;

$\square$ Issue stocks or consult for a bank credit to build its working capital; capital;

Make choices with respect to contributing or loaning

$\square$ Other choices that enable administration to make an educated determination on different options in the direct of its business.

\section{DATA ANALYSIS AND INTERPRETATION}

- Ratio Analysis

- Liquidity Ratios

Current Ratio

Quick Ratio

Fixed Assets Turnover Ratio

Current Assets to Fixed Assets

Table - 1 Current Ratio

\begin{tabular}{|l|l|l|l|}
\hline \multicolumn{4}{|l|}{ Current Ratio } \\
\hline Year & Current Assets & Current Liabilities & Current Ratio \\
\hline $\mathbf{2 0 1 3}$ & 396.88 & 215.93 & 1.84 \\
\hline $\mathbf{2 0 1 4}$ & 352.25 & 166.23 & 2.12 \\
\hline $\mathbf{2 0 1 5}$ & 360.33 & 218.74 & 1.65 \\
\hline $\mathbf{2 0 1 6}$ & 379.18 & 211.98 & 1.79 \\
\hline $\mathbf{2 0 1 7}$ & 400.16 & 250.68 & 1.60 \\
\hline
\end{tabular}

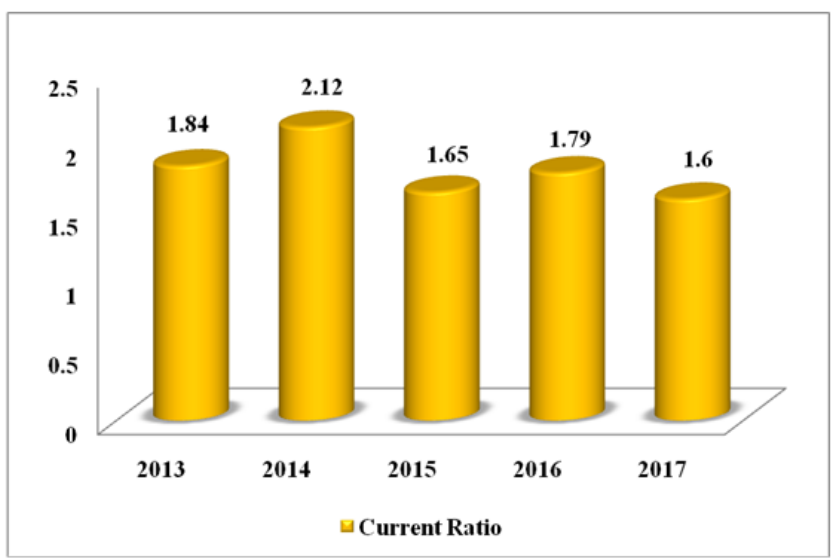

Table - 2 Quick Ratio

\begin{tabular}{|l|l|l|l|}
\hline \multicolumn{4}{|l|}{ Quick Ratio } \\
\hline Year & Quick Assets & Current Liabilities & Quick Ratio \\
\hline $\mathbf{2 0 1 3}$ & 260.36 & 215.93 & 1.21 \\
\hline $\mathbf{2 0 1 4}$ & 239.67 & 166.23 & 1.44 \\
\hline $\mathbf{2 0 1 5}$ & 257.63 & 218.74 & 1.18 \\
\hline $\mathbf{2 0 1 6}$ & 285.61 & 211.98 & 1.35 \\
\hline $\mathbf{2 0 1 7}$ & 271.97 & 250.68 & 1.08 \\
\hline
\end{tabular}

Revised Manuscript Received on July 22, 2019.

Mr. CS Gowtham Chakravarthy Department of MBA, Bharath Institute of Higher Education and Research, Chennai, India.

Email: chakravins@gmail.com

Dr. S. Praveen Kumar, Department of MBA, Bharath Institute of Higher

Education and Research, Chennai, India.

Email: praveenkumar.mba@bharathuniv.ac.in 


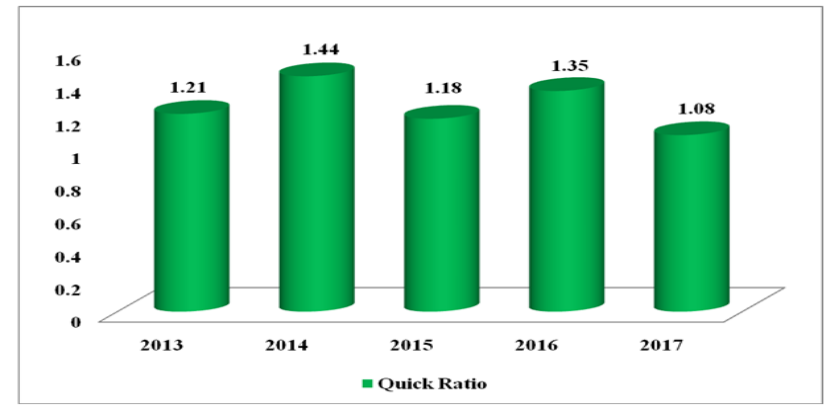

Table - 3 Fixed Assets TurnOver Ratio

\begin{tabular}{|l|l|l|l|}
\hline \multicolumn{4}{|l}{ Fixed Assets Turnover Ratio } \\
\hline Year & Income from service & Net Fixed Assets & Ratio \\
\hline $\mathbf{2 0 1 3}$ & 787.67 & 234.82 & 3.35 \\
\hline $\mathbf{2 0 1 4}$ & 858.77 & 310.49 & 2.77 \\
\hline $\mathbf{2 0 1 5}$ & 671.92 & 303.80 & 2.21 \\
\hline $\mathbf{2 0 1 6}$ & 763.96 & 274.57 & 2.78 \\
\hline $\mathbf{2 0 1 7}$ & 881.60 & 263.72 & 3.34 \\
\hline
\end{tabular}

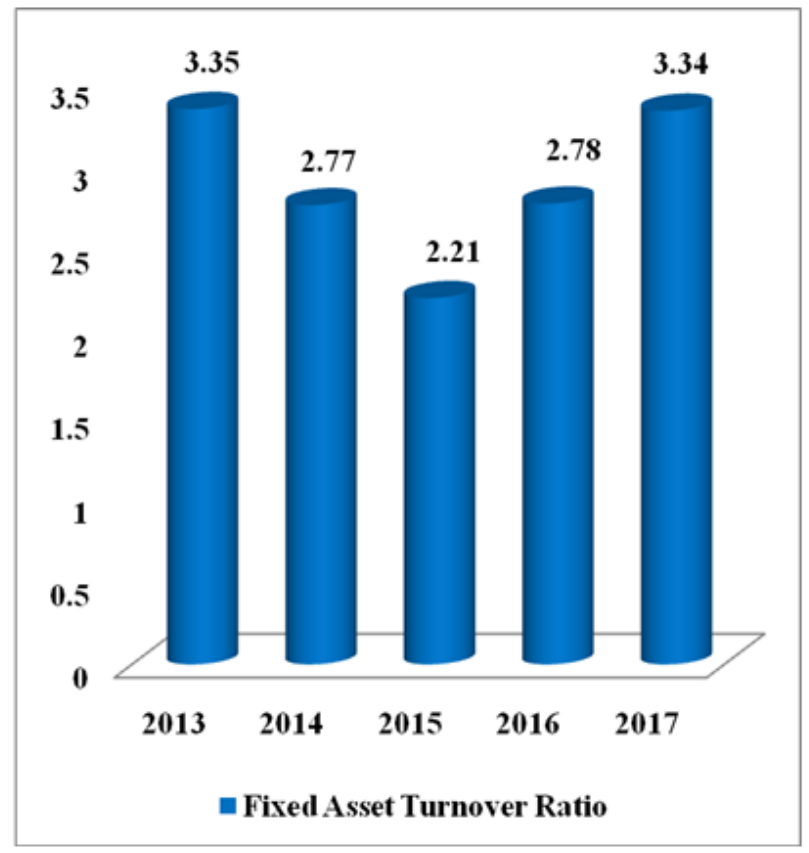

Table - 4 Current Assets to Fixed Assets Ratio

\begin{tabular}{|l|l|l|l|}
\hline \multicolumn{4}{|l|}{ Current Assets To Fixed Assets Ratio } \\
\hline Year & Current Assets & Fixed Assets & Ratio \\
\hline $\mathbf{2 0 1 3}$ & 396.88 & 234.82 & 1.69 \\
\hline $\mathbf{2 0 1 4}$ & 352.25 & 310.49 & 1.13 \\
\hline $\mathbf{2 0 1 5}$ & 360.33 & 303.80 & 1.19 \\
\hline $\mathbf{2 0 1 6}$ & 379.18 & 274.57 & 1.38 \\
\hline $\mathbf{2 0 1 7}$ & 400.16 & 263.72 & 1.52 \\
\hline
\end{tabular}

Table - 5 Debt to Equity Ratio

\begin{tabular}{|l|l|l|l|}
\hline Year & Total Debt & Net worth & Debt to Equity Ratio \\
\hline $\mathbf{2 0 1 3}$ & 192.03 & 223.11 & 0.86 \\
\hline $\mathbf{2 0 1 4}$ & 256.59 & 239.52 & 1.07 \\
\hline $\mathbf{2 0 1 5}$ & 338.52 & 106.37 & 3.18 \\
\hline $\mathbf{2 0 1 6}$ & 324.21 & 117.31 & 2.76 \\
\hline $\mathbf{2 0 1 7}$ & 329.54 & 83.92 & 3.93 \\
\hline
\end{tabular}

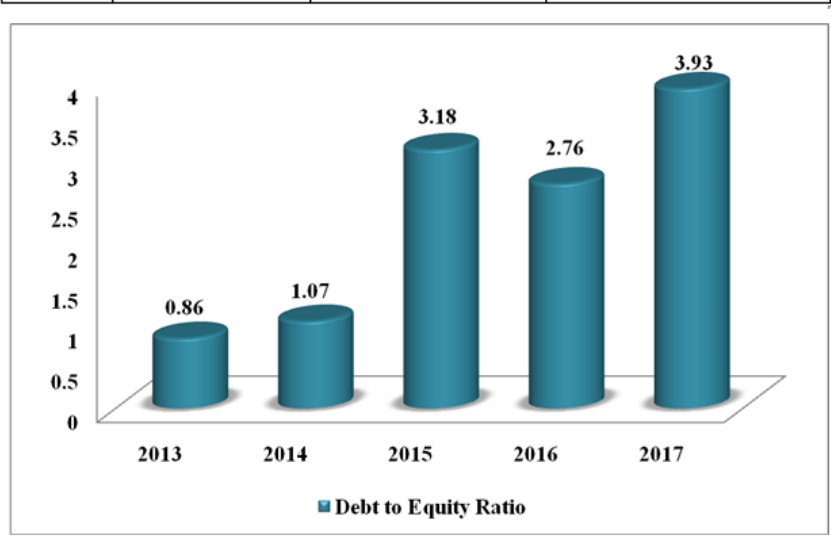

Table - 6 Debt to Asset Ratio

\begin{tabular}{|l|l|l|l|}
\hline Year & Total Debt & Total Assets & Debt to Assets Ratio \\
\hline $\mathbf{2 0 1 3}$ & 192.03 & 416.3 & 0.46 \\
\hline $\mathbf{2 0 1 4}$ & 256.59 & 496.78 & 0.52 \\
\hline $\mathbf{2 0 1 5}$ & 338.52 & 445.5 & 0.76 \\
\hline $\mathbf{2 0 1 6}$ & 324.21 & 442.02 & 0.73 \\
\hline $\mathbf{2 0 1 7}$ & 329.54 & 413.45 & 0.80 \\
\hline
\end{tabular}

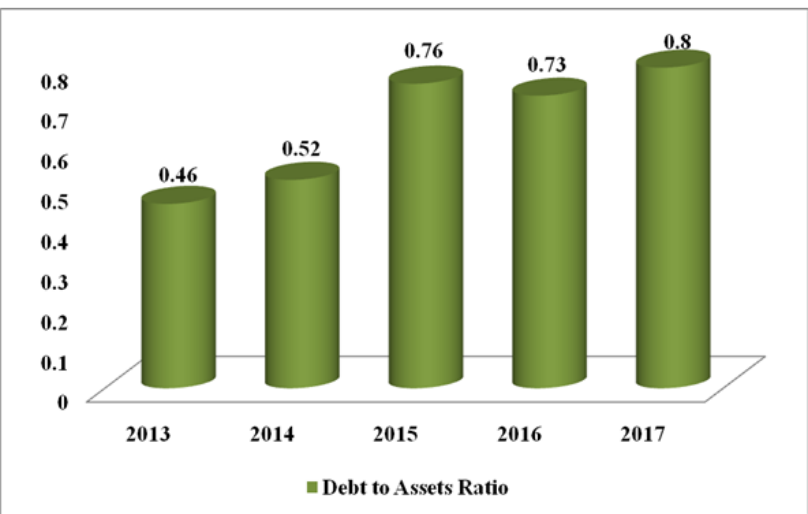

Table - 7 Interest Coverage Ratio

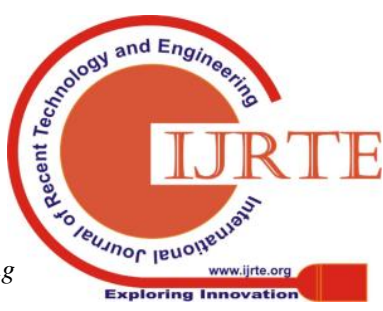




\begin{tabular}{|l|l|l|l|}
\hline Year & Operating Income & Interest Expenses & Interest Coverage Ratio \\
\hline $\mathbf{2 0 1 3}$ & 87.44 & 10.86 & 8.05 \\
\hline $\mathbf{2 0 1 4}$ & 26.08 & 16.5 & 1.58 \\
\hline $\mathbf{2 0 1 5}$ & 5.01 & 28.06 & 0.18 \\
\hline $\mathbf{2 0 1 6}$ & 96.61 & 34.97 & 2.76 \\
\hline $\mathbf{2 0 1 7}$ & 45.93 & 31.43 & 1.46 \\
\hline
\end{tabular}

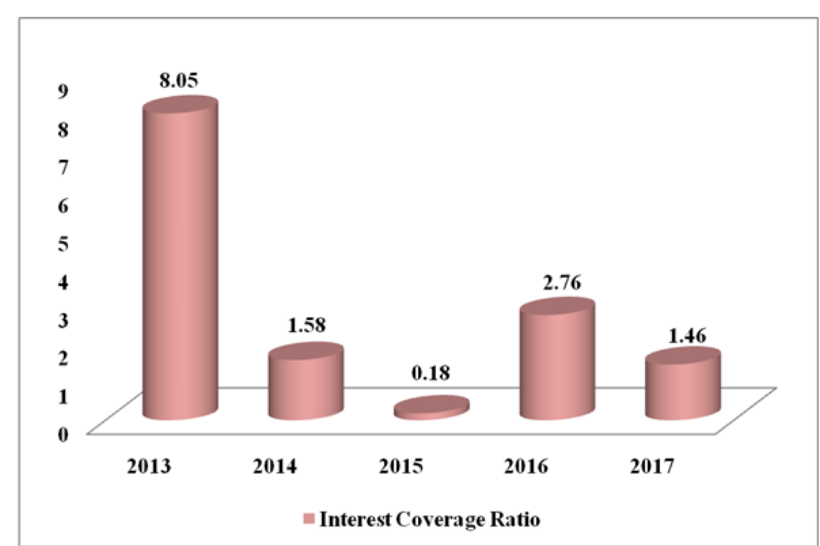

PROFITABILITY RATIOS

- Operating Ratio

- Net Profit Ratio

\section{A. Operating Ratio}

Table - 8 Operating Ratio

\begin{tabular}{|l|l|l|l|}
\hline Year & Operating expense & Net sales & Operating ratio \\
\hline $\mathbf{2 0 1 3}$ & 83.57 & 773.48 & 0.11 \\
\hline $\mathbf{2 0 1 4}$ & 63.67 & 820.97 & 0.08 \\
\hline $\mathbf{2 0 1 5}$ & 39.26 & 764.58 & 0.05 \\
\hline $\mathbf{2 0 1 6}$ & 39.39 & 801.92 & 0.05 \\
\hline $\mathbf{2 0 1 7}$ & 25.22 & 808.92 & 0.03 \\
\hline
\end{tabular}

\section{Interpretation:}

Operating ratio for the years 2013, 2014, 2015, 2016 and 2017 gradually decreased from 0.11 to 0.03 .

Table - 9 Trend Analysis of Current Assets

\begin{tabular}{|l|l|l|l|l|l|l|}
\hline YEAR & $\mathbf{X}$ & $\mathbf{Y}$ (Rs.lakhs) & $\mathbf{X}^{\mathbf{2}}$ & $\begin{array}{l}\text { XY } \\
\text { (Rs.lakhs) }\end{array}$ & $\begin{array}{l}\text { TREND } \\
\text { VALUE }\end{array}$ & DEVIATION \\
\hline $\mathbf{2 0 1 3}$ & -2 & 338.38 & 4 & -676.76 & 323.142 & 15.24 \\
\hline $\mathbf{2 0 1 4}$ & -1 & 300.53 & 1 & -300.53 & 316.793 & -16.26 \\
\hline $\mathbf{2 0 1 5}$ & 0 & 296.92 & 0 & 0 & 310.444 & -13.52 \\
\hline $\mathbf{2 0 1 6}$ & 1 & 318.98 & 1 & 318.98 & 304.095 & 14.89 \\
\hline $\mathbf{2 0 1 7}$ & 2 & 297.41 & 4 & 594.82 & 297.746 & -0.34 \\
\hline TOTAL & & $\mathbf{1 , 5 5 2 . 2 2}$ & $\mathbf{1 0}$ & $\mathbf{- 6 3 . 4 9}$ & & \\
\hline
\end{tabular}

Table - 10 Projected Trend Value - Current Assets For The Forthcoming Years (2014 To 2017)

\begin{tabular}{|l|l|}
\hline YEAR & FUTURE TREND (Trend value + B) \\
\hline 2017 & 297.75 \\
\hline 2018 & 291.4 \\
\hline 2019 & 285.05 \\
\hline 2020 & 278.70 \\
\hline 2021 & 272.35 \\
\hline
\end{tabular}

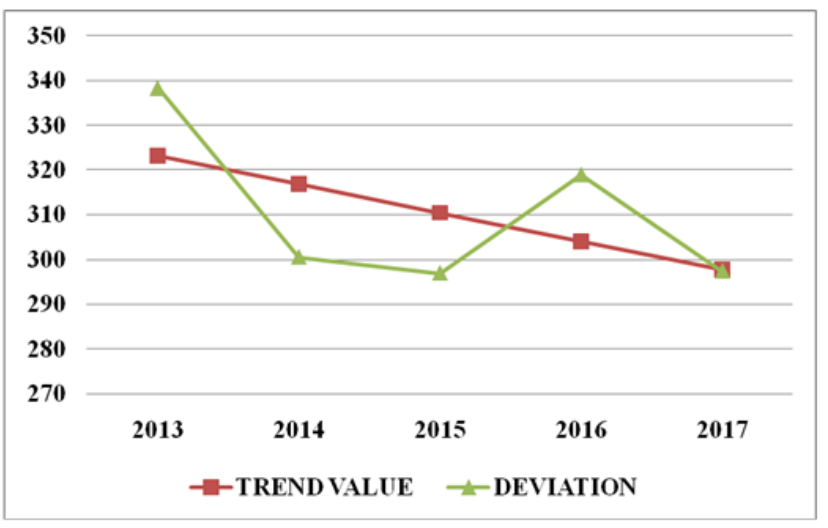

Figure 1 - Trend and Deviation

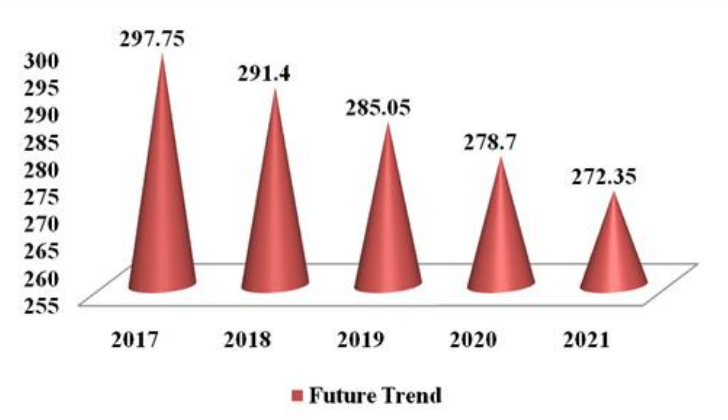

Figure 2 - Trend Analysis of Current Assets

Table - 11 Trend Analysis of Current Liabilities

\begin{tabular}{|l|l|l|l|l|l|l|}
\hline YEAR & $\mathbf{X}$ & $\mathbf{Y}$ (Rs.lakhs) & $\mathbf{X}^{\mathbf{2}}$ & $\begin{array}{l}\text { XY } \\
\text { (Rs.lakhs) }\end{array}$ & $\begin{array}{l}\text { TREND } \\
\text { VALUE }\end{array}$ & DEVIATION \\
\hline $\mathbf{2 0 1 3}$ & -2 & 209.16 & 4 & -418.32 & 182.494 & 26.67 \\
\hline $\mathbf{2 0 1 4}$ & -1 & 157.01 & 1 & -157.01 & 193.819 & -36.81 \\
\hline $\mathbf{2 0 1 5}$ & 0 & 214.00 & 0 & 0 & 205.144 & 8.86 \\
\hline $\mathbf{2 0 1 6}$ & 1 & 202.52 & 1 & 202.52 & 216.469 & -13.95 \\
\hline $\mathbf{2 0 1 7}$ & 2 & 243.03 & 4 & 486.06 & 227.794 & 15.24 \\
\hline TOTAL & & $\mathbf{1 , 0 2 5 . 7 2}$ & $\mathbf{1 0}$ & $\mathbf{1 1 3 . 2 5}$ & & \\
\hline
\end{tabular}

Table - 12 Projected Trend Value - Current Liabilities For The Forthcoming Years (2015 To 2017)

\begin{tabular}{|l|l|}
\hline YEAR & FUTURE TREND (Trend value + B) \\
\hline 2017 & 227.79 \\
\hline 2018 & 239.12 \\
\hline 2019 & 250.44 \\
\hline 2020 & 261.77 \\
\hline 2021 & 273.09 \\
\hline
\end{tabular}




\section{RESULTS}

- It can be seen that there is fluctuating pattern during the investigation time frame. In the year 2014, it expanded to 2.12 from 1.84. It diminished to 1.65 in the year 2015 and it finds a slight ascent to 1.79 in the year 2016. In the year 2017 it again diminished to 1.60. The administration should take medicinal measures to improve the present position[7],[9],[11]

- In the year 2014 it expanded to 1.44 from 1.21 of 2013. The above chart it very well may be seen that there is fluctuating pattern during the investigation time frame. In the year 2016 it expanded to 1.35 and falls again to 1.08 in 2017.

- It can be seen that there is fluctuating pattern during the investigation time frame. In the year 2013 and 2014 it was in its pinnacle of 3.35 and 2.77 and falls profound to 2.21 in 2015 and there on it is expanded and recovered its underlying level

- The obligation value proportion demonstrates a development from 0.86 in 2013 to 3.18 in 2015, in 2016 found a little decay and again rose to 3.93 . This demonstrates a negative sign and the organization ought to limit the buys of stock or fixed resources in future years.

- The Debt to resources proportion was observed to be in a decent rate in 2013 and 2014 which is beneath half, yet there after in the fourth coming years, it expanded. This demonstrates a conceivable abuse of influence, and it might show potential issues meeting the obligation installments. [8],[10],[12]

- The obligation to value proportion is observed to be in a superior rate in the year 2013 however abruptly falls steeply to 1.58 in 2014 and 0.18 in 2015 . This was extremely an emergency period however by one way or another figured out how to increment to 2.76 and 1.46 in 2016 and 2017 separately. It's an unmistakable sign that the organization's budgetary hazard is expanding.

- Operating proportion for the years 2013, 2014, 2015, 2016 and 2017 continuously diminished from 0.11 to 0.03

- During the year 2013, the working benefit proportion was 0.07 and it diminished to 0.03 in 2014 and ended up negative during 2015, however again expanded to 0.01 in 2016 and 0.03 in 2017

- From the normal size monetary record of Bharat Plastics for the year 2013 and 2014 it is seen that the organization's present resources got an unexpected soak from $81.28 \%$ to $60.50 \%$ pursued by 2013 and 2014. The organization fixed resources did not demonstrate a much deviation. The organization capital, surplus and stores are consistent. At long last it very well may be inferred that the general monetary position of the organization is fulfilled[13], [15],[17]
From the normal size accounting report of Bharat Plastics for the year 2014 and 2015 it is seen that the organization's present resources expanded from $60.50 \%$ to $66.65 \%$ pursued by 2014 and 2015. The organization fixed resources expanded from $51.42 \%$ to $60.32 \%$ pursued by 2014 and 2015. The organization capital, surplus and stores are consistent. At long last it tends to be inferred that the general budgetary position of the organization is fulfilled.

- The organization's present resources expanded from $66.64 \%$ to $72.16 \%$ pursued by 2015 and 2016. The organization fixed resources diminished from $60.32 \%$ to $55.25 \%$ pursued by 2015 and 2016. The organization capital, surplus and stores are steady. At last it tends to be reasoned that the general monetary position of the organization is fulfilled.

- The regular size accounting report of Bharat Plastics for the year 2016 and 2017 uncovered that the organization current resources diminished from $72.16 \%$ to $71.93 \%$ pursued by 2016 and 2017. The organization fixed resources diminished from $55.26 \%$ to $60.08 \%$ pursued by 2016 and 2017. The organization capital, surplus and stores are steady. At long last it tends to be presumed that the general budgetary position of the organization is fulfilled.

- The relative accounting report of Bharat Plastics for the year 2013 and 2014, the organization's present resources expanded from 496.11 to 415.14 . The similar monetary record of the organization demonstrates that the general budgetary position of the organization is great[14],[16], [18]

- The relative monetary record of Bharat Plastics for the year 2014 and 2015 uncovers that the organization's present resources diminished from 496.11 to 444.89 . The similar monetary record of the organization demonstrates that during these years the advantages worth confronted an abrupt fall this may be because of lessening in inventories and capital work in advancement

- The similar accounting report of Bharat Plastics for the year 2015 and 2016 uncovers that the organization's present resources diminished from 444.89 to 441.52 . The near monetary record of the organization demonstrates that during these years the advantages worth confronted a slight fall this may be because of reduction in inventories and net fixed resources

- The near monetary record of Bharat Plastics for the year 2016 and 2017 says that the organization's present resources diminished from 496.11 to 444.89 . The near accounting report of the organization demonstrates that during these years the advantages worth confronted an unexpected fall this may be because of decline in sundry indebted individuals and capital work in advancement

The working capital articulation of Bharat Plastics for the year 2013 and 2014 uncovers that the Current resources of the organization demonstrate a profound declining pattern from the year 
2013-2014. Current liabilities decay from 2013 - 2014. This was extremely a decent sign and ideal to the association.

- From the working capital articulation of Bharat Plastics for the year 2014 and 2015, it is realized that Current resources of the organization demonstrated a moderate raise from the earlier year. Current liabilities expanded. In spite of the fact that this isn't ideal to the organization net resources remunerated such a decrease[19],[21],[23]

- From the working capital articulation of Bharat Plastics for the year 2015 and 2016, we found that the Current resources of the organization demonstrated a moderate raise from the earlier year. Current liabilities expanded. In spite of the fact that this isn't positive to the organization net resources repaid such a decrease.

- The working capital articulation of Bharat Plastics for the year 2016 and 2017 says that the present resources of the organization demonstrated a moderate raise from the earlier year. Current liabilities expanded. In spite of the fact that this isn't positive to the organization net resources repaid such a decrease. [20],[22],[24]

- The pattern examination for the investigation time frame demonstrates just a negligible increment. This is chiefly because of the reason that these information's have been landed in examination with the most recent 5 years fixed resources esteem. There was no extraordinary increment in development in term of advantages during 2017 and this is the one of the significant reasons that the projections are additionally demonstrating just a negligible increment. As a general rule in the event that we expect that the equivalent expanding in pattern proceeds contrasted with 2016, the proportion for the over five years will be as yet higher[25],[27],[29].

\section{DISCUSSIONS}

After the assessment of Financial Statements, the association status is better, in light of the way that the Net working capital of the association is increased from the latest year's position.

$\square$ The association advantages are gigantic in the present year; it is more brilliant to articulate the benefit to accomplices.

$\square$ The association is utilizing the fixed assets, which altogether help to the improvement of the affiliation. The association should keep up that wonderfully[26],[28],[30].

$\square$ The association fixed stores are raised from the commencement, it gives the other compensation i.e., Interest on fixed stores.

$\square$ Steps must be taken to grow the present asset position of the firm so as to improve the liquidity position of the firm.
Percentage of commitment to esteem can be diminished so as to decrease the budgetary peril.

\section{CONCLUSION}

Bharat Plastics is demonstrating variances in its gainfulness position from the previous 5 years, which is finished up with the budget summary examination.

The earlier year resources were likewise expanded however its working capital position was diminishing which says that the organization was not able meet its present liabilities[31],[33].

- Preparation of fiscal reports empowers the Government to see if the association is following different principles and guidelines or not. These announcements give a base to the guideline for the firm.

- The fiscal reports are valuable for getting to the productivity for various cost focuses as the administration can exercise cost control through these announcements.

- It isn't just useful to dissect the present budgetary position yet it will likewise contemplate future prospects and development plans of the worry

\section{REFERENCES}

1) BharthVajan R., Ramachandran S.,Psychographic dimensions of training,2016,International Journal of Pharmacy and Technology,V-8,I-4,P-23727-23729

2) Balakrishnan P., Bharthvajan R.,A study on human resource planning in hospitals in Chennai City,2014,International Journal of Applied Engineering Research,V-9,I-22,P-7503-7507

3) Priyadarsini P., Bharthvajan R.,Role of emotional intelligence training programme in reducing the stress of the nurses,2014,International Journal of Applied Engineering Research,V-9,I-22,P-7411-7421

4) Kerinab Beenu G., Bharthvajan R.,Empirical analysis on the cosmetic buying behavior of young women in South India,2014,International Journal of Applied Engineering Research,V-9,I-22,P-7361-7366

5) Balakrishnan P., Bharthvajan R.,Whistling in the wind,2014,International Journal of Applied Engineering Research,V-9,I-22,P-7586-7593

6) Krishnan B., Peter M.,Health hazards of Indian Bpo employee-an alarming issue,2014,International Journal of Applied Engineering Research,V-9,I-22,P-7336-7341

7) Kerinab Beenu G.H., Peter M.,Role of insurance in economic development,2014,International Journal of Applied Engineering Research,V-9,I-22,P-7532-7539

8) Balakrishnan P., Peter M., Priyadarsini P.,Efficiency of safety measures for wellbeing of employees in manufacturing industry,2014,International Journal of Applied Engineering Research,V-9,I-22,P-7376-7382

9) Anbarasi M., Praveen Kumar S.,Online sales promotions of herbal products and its effectiveness towards tanisha.com,2019,Indian Journal of Public Health Research and Development,V-10,I-1,P-195-200

10) Anbarasi M., Praveen Kumar S.,Various online marketing and promotions strategies to improve the validation towards the organic products in the pharmaceutical sectors,2019,Indian Journal of Public Health Research and Development,V-10,I-1,P-263-269

11) Loganathan R., Praveen Kumar S.,Grievance handling a key factor for solving issues of employees in an organization,2014,International Journal of Applied Engineering Research,V-9,I-22,P-7483-7491

12) Loganathan R., Praveen Kumar S.,Study on preference of private label brands in super and Hypermarkets,2014,International Journal of Applied Engineering Research,V-9,I-22,P-7327-7335

13) Smitha M., Praveen Kumar S.,Understanding stress and its managementamong the nurses in Chennai city,2014,International Journal of Applied Engineering Research,V-9,I-22,P-7560-7565

14) Kerinab Beenu G.H., Praveen Kumar S.,A study on the investment behavior of Chennai investors in mutual fund schemes,2014,International Journal of Applied Engineering Research,V-9,I-22,P-7520-7525

15) Loganathan R., Praveen Kumar S.,Retention strategies key for organizational productivity,2014,International Journal of Applied Engineering Research,V-9,I-22,P-7443-7447

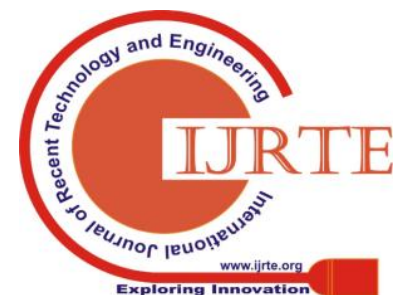


16) Pavithra J., Ganesan M., Brindha G.,State wise analysis of microfinance sector in India,2016,International Journal of Pharmacy and Technology,V-8,I-4,P-23417-23432

17) Pavithra J., Ganesan M.,A comparative study on microfinance in India and abroad,2016,International Journal of Applied Business and Economic Research,V-14,I-8,P-5471-5476

18) Pavithra J., Ganesan M.,A study on awareness and impact of micro-financial schemes,2016,International Journal of Applied Business and Economic Research,V-14,I-8,P-5449-5460

19) Senthilmurugan P., Pavithra J.,Consumer preference towards organised retailing with reference to Big Bazaar,2014,International Journal of Applied Engineering Research,V-9,I-22,P-7469-7475

20) Senthilmurugan P., Pavithra J.,Implication of social media marketing in growing healthcare industry,2014,International Journal of Applied Engineering Research,V-9,I-22,P-7448-7456

21) Loganathan R., Pavithra J.,Consumer perception towards private label brand over other brands in super markets and hypermarkets,2014,International Journal of Applied Engineering Research,V-9,I-22,P-7355-7360

22) Kerinab Beenu G., Pavithra J.,Tradeâ€"off between liquidity and profitability in logistics industry,2014,International Journal of Applied Engineering Research,V-9,I-22,P-7398-7401

23) Kerinab Beenu G., Pavithra J.,A study on the prospective consumerâ€ ${ }^{\mathrm{TM}_{\mathrm{S}}}$ perception towards utility cars in Chennai city,2014,International Journal of Applied Engineering Research,V-9,I-22,P-7526-7531

24) Pavithra J., Dilli Babu P., Ambuli T.V.,A study on budgetary control at Maruti Service Masters, Chennai,2014,International Journal of Applied Business and Economic Research,V-12,I-2,P-151-161

25) Pavithra J., Dilli Babu P., Ambuli T.V.,A study on customer satisfaction of retro Garments Pvt Ltd, Chennai,2014,International Journal of Applied Business and Economic Research,V-12,I-2,P-381-391

26) Kerinab Beenu G.H., Pavithra J., Senthilmurugan P.,A study on the influence of promotional activities for TATA ARIA among consumers in Chennai,2014,International Journal of Applied Engineering Research,V-9,I-22,P-7572-7578

27) Vijayaragavan S.P.,An investigative expert that's general FBG sensors,International Journal of Mechanical Engineering and Technology,V-8,I-8,PP-1500-1505,Y-2017

28) Vijayaragavan S.P.,Equalization routing protocol for Wi-Fi sensor strategy,International Journal of Mechanical Engineering and Technology,V-8,I-8,PP-1662-1666,Y-2017

29) Karthik B., Kiran Kumar T.V.U., Vijayaragavan P., Bharath Kumaran E.,Design of a digital PLL using 0.35 $\hat{\mathrm{I}}^{1 / 4 \mathrm{~m}}$ CMOS technology, Middle East Journal of Scientific Research,V-18,I-12,PP-1803-1806,Y-2013

30) Kanniga E., Selvaramarathnam K., Sundararajan M.,Kandigital bike operating system,Middle - East Journal of Scientific Research,V

31) Jasmin M., Vigneshwaran T., Beulah Hemalatha S.,Design of power aware on chip embedded memory based FSM encoding in FPGA,International Journal of Applied Engineering Research,V-10,I-2,PP-4487-4496,Y-2015

32) Jasmin M.,Optimization techniques for low power VLSI circuits, Middle East Journal of Scientific Research,V-20,I-9,PP-1082-1087,Y-2014

33) Jasmin M., Vigneswaran T.,Fuzzy controller for error control of on - Chip communication,2017 International Conference on Algorithms, Methodology, Models and Applications in Emerging Technologies, ICAMMAET 2017,V-2017-January,I-,PP-1-5,Y-2017

\section{AUTHORS PROFILE}

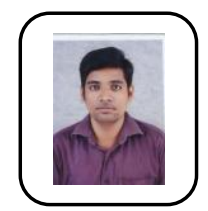

Mr. CS Gowtham Chakravarthy Assistant Professor, Department of MBA, Bharath Institute of Higher Education and Research, Chennai, India.

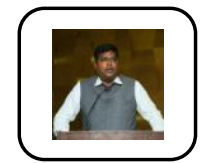

Dr. S. Praveen Kumar Professor, Department of MBA, Bharath Institute of Higher Education and Research, Chennai, India. 